\title{
Augustus - The Engineering of Belief \& the Pax Deorum Part 2 in a Serial Study of the Pax Deorum
}

\begin{abstract}
David P. Wick
The Emperor Augustus would believe at the end of his life that he had rekindled at least a functioning image of the archaic Roman religious spirit in the major arteries of his empire and at least in its Greek and Italian regions, and in his city. His contemporaries seem to have agreed that they could see this happening, even when they acknowledged it as an act of propaganda in some sort. Modern scholars have been more inclined to see through it, or to see only the propaganda, or an event staged by a managed, state religion. My intent in this study - the second of three parts (Wick (2019a \& 2019b) - has been to examine the attempt by Augustus to stage (before and during the year 17 of the old era) what he hoped or argued would be a transformative event, one that might re-create the family religious solidarity and wholeness of community he and his wife believed the Roman world needed to survive. This study focuses on the design of the Saeculares event itself - its use of 'captive' popular literature, themes of family and repentance in ritual acts, objects and liturgy, uses of the symbolic teaching nature of spaces in the Roman cityscape, and the participation of Augustus and his wife themselves (and their use of their own property in the cityscape to press the redeeming nature of the rather non-Roman god Apollo) as well as the Greek birth-deity Eilithyia.
\end{abstract}

Keywords: Ancient Studies, Roman Religion, Political/Social History, Augustus, Early Roman Empire.

Roman you will pay for your forefathers' sins

Till you rebuild gods' temples from ruins,

Roofs of worm-eaten oak,

Statues filthy with smoke.

To be below the gods your rule defends

To this fix all beginnings and all ends.

Gods take a heavy fee

From wailing Italy...

The poet Horace, whose lines here I used in the first part of this study (and use them again to set the focus) was at once a distant friend of, and often a daring critic of, Octavian's new regime. He had a habit of sounding this note periodically

"Professor, Gordon College, USA.

${ }^{1}$ Horace, Odes, III, vi, ll 1-8, the translation this time from P. Levi, Horace: a Life (New York, 1998).

https://doi.org/10.30958/ajms.5-2-1

doi=10.30958/ajms.5-2-1 
and pointedly, first in opposition to the party and family of the 'Augustus' that Octavian would become; and later, discovering he was an insider, as a corrective to his chattier and more personally reflective writings.

I argued in the article beginning this series that Augustus seems not only to have undergone a conversion of his own on matters of deity and definition of life in the aftermath of the Battle of Actium and what political historians call 'the Settlement of 29," but also to have shared with his generation of political players and thinkers an interest in the general subject of regeneration or even salvation. Rome, its existence as well as character, the pax deorum of Rome (or the peace if tried to maintain with the gods was broken fatally, and itself needed healing. He set more store by his own initiation into the Eleusinian mysteries before he left Athens for Italy, than one might have expected from a Roman of his public character. ${ }^{2}$ (Jones 1970) A similar initiation, on Italian soil, appeared for the purification of the hero of the Aeneid, a poem which must have been much discussed at every stage of its composition in the Augustan circle. ${ }^{3}$ (Fowler 1911, Mazzolani 1970: 175) The great act ... acts ... of 'spiritual engineering, though there were the Ludi Saeculares of 17 B.C.

\section{The Ludi Saeculares}

I suggested as I finished the previous study in this series that the great national festival of the Saeculares makes the proper hinge on which to hang any discussion of Augustan public 'propaganda', but also that it makes a more useful hinge if we recollect carefully how we are defining the beast -- the word is one we use frequently in the twentieth century, usually with emotion and seldom without disdain. The meaning operative here I gave last year. Even the cheaper sort of propaganda attempts an act of definition, an unprincipled coloring of actual things in the hope they will begin to look in public as the author wished them to. High propaganda (there are better words for it, but we are usually too sophisticated to get much use out of them $)^{4}$ hopes by some force or character of its proclamation to give an idea or intention actuality.

Augustus had by the year 17, a decade from the solidifying of his regime, spent a great deal of effort attempting to return the appearance of a functioning

\footnotetext{
${ }^{2}$ Jones also quotes (p. 148) without fully catching its spirit, the stanza from the Carmen Saeculare in which Horace (or better Augustus, I suspect) agonizes over "generations fertile in guilt" and almost manages to drag the lex maritandis visibly into the worship. The bachelors of the Roman political elite, after all, were present for once.

${ }^{3}$ W. Warde Fowler, Religious Experience of the Roman People (1911), cap. XVIII: "Religious Feeling in the Poems of Virgil", pp. 403-427.

4"Prophecy" perhaps, in the poetic sense of the word, or even "evangelism". When dealing with the central motivations of human hearts in historical settings -- even when those motivations might be materialist, pecuniary, dynastic, or simply egotistical -- religious words are precisely not out of place.
} 
Republic to many parts of the civic life of Rome. There was less illusion about this than has sometimes been thought. The Asian governor who spoke of the years before Actium in terms of suicide (I quoted this in last year's study) struck the right note -- "restored to serviceability, if not to its natural state." ${ }^{5}$ (Johnson et al. 1961, Price 1984, cf. Ehrenberg and Jones 1949, Dittenberger 1905, Lewis and Reinhold 1966, Gruen 1974). Augustus had just pushed through a series of moral legislations in the teeth of considerable grumbling among the nobility. His program of temple repair, of refounding the infrastructure -- if you like -- of the pax deorum was well on toward completion. He proposed before long to spend some considerable time in the provinces. Agrippa would also be abroad. Before he left there were two things to attend to: regularizing the position of his grandsons Gaius and Lucius as heirs, and setting the physical and spiritual regeneration of Rome on a sound basis. To judge by the intensity of his activity in our surviving accounts, he gave the second of these activities as least as much weight as the first. He was not engaged in a simple exercise of display. At worst he would have reestablished the peace of his city with the gods before his absence. At best some real purification and definition might take place in the hearts or heads of his capital's people.

The sheer importance of this within the context of its time is often missed by historians of mere political mechanics. The literature and even the street-corner speakers of the late Republic had been broadcasting the idea that the world was nearing the end of an age. Either a new age was coming, or blind chaos. ${ }^{6}$ (Dodds

\footnotetext{
${ }^{5}$ The quotation, and the references, in case part 1 of the study is not available. "We could justly hold it (the birthday of Augustus) to be equivalent to the beginning of all things, and he has restored to serviceability, if not to its natural state, every form that had become imperfect and fallen into misfortune, and he has given a different aspect to the whole world, which blithely would have embraced its own destruction if Caesar had not been born for the common benefit of all. Therefore people would be right to consider this to have been the beginning of the breath of life for them, which has set a limit to regrets for having been born." Ancient Roman Statutes, ed. A.C. Johnson et al (1961), no. 119. See also the chapter "Greeks and Rome" in S.R.F. Price, Rituals and Power: the Roman Imperial Cult in Asia Minor (Cambridge, 1984), pp. 53-77. Price is better with the details than with the feeling of the evidence he handles in my view, but has some enlightening points to make about the role of Roman provincial magistrates in personalizing and even Romanizing the Hellenic view of Augustus.

${ }^{6}$ Horace, Odes, III, vi, 46 ff.; Epodes, xvi. Lucretius II, 1150-1174 and V, 826 ff. This reaches its ultimate low point in Seneca, Nat. Qu. III, 27-30 and his Epistle XC, 40, 44. On Romulus as calendary founder of the first Roman age now drawing to its end, and the theurgic magic exerted by calendar-making on the functioning of time see Ovid, Fasti I, $27 \mathrm{ff}$. By this view Caesar had dislocated and revised the very mechanics of the cosmos (Scott 1933, Jeanmaire 1924). The acquaintance of Julius Caesar's circle with Egyptian "astral science" and with experts in it of international reputation (like Sosigenes) was considerable, and we would be ill-advised to interpret any ancient calendary reform in a purely scientific or practical light. The assassins chose, for whatever reason, to act precisely upon the Anna Perenna, the initial day of the old Romulan year. Cf. Macrobius, Saturnalia I, xvi, 39, which preserves the tradition that Caesar's attention to astronomy was in general very Egyptian, and that a treatise of his own on it was for a long time extant (cf Taylor 1931, Maasolani 1970).
} 
1972: 17-22, Pasquali 1931: 297) Virgil and Horace had put the optimistic view with varying degrees of politeness and real enthusiasm, ${ }^{7}$ but behind them were philosophical writers and culture critics like $\operatorname{Varro}^{8}$ and a great deal of (lost) cataclysmic Egyptian-Antonine propaganda. No intelligent skeptic would have wasted so much political and spiritual capital.

To Augustus, for whom each of the continuing scandals, social problem and mutinies in the city probably created fresh private doubts about his handling of the diving peace, the issue was critical. It hardly mattered that Antony was gone from the world; for over a century Rome had shown an astonishing genius for ending one civil war only with a false lull that carried in it the seeds of the next (and sharper) wave of violence. At some point, a new era had to be seen to really begin.

If not, it would always seem by default to have begun at Actium with only the push and shove of enormous physical forces to make it legitimate. The rather leaned-out remnants of those forces remained of course; the legions sat on the frontiers like shadows of Actium. But while they could place Rome under arrest, or loot it, they could never make it work. The pax deorum of the legions worried the emperor too, but that of the city most of all. It must come first, as he intended it to define the provinces he was melding into an empire. Augustus put all his tools in a row for this work.

First, he intended that everyone, in symbol at least, should be present. The law de maritandis ordinibus of the previous year which prohibited bachelors from attending public events was waived just this once. (Fowler 1911: 442) On the evening of 26, 27 and 28 May priests distributed torches, sulphur and bitumen to all free individuals, regardless of citizenship. The people purified themselves by such means and made agricultural offerings in the old Roman manner.'

When the city was thus symbolically clean Augustus went on the night before the $1^{\text {st }}$ of June, down into the cavernous little shrine under the Tiber banks of the Campus Martius called Tarentum and began a series of torchlit sacrifices to the darker side of the new rebirth. The place had a tradition of connoting Roman regeneration which Zosimus has preserved along with the details of the festival. ${ }^{10}$ The first night the Emperor and Agrippa propitiated the Fates, not only the dark definers of past and future from Greek mythology but also in their hope the beneficial fata Iovis that recurrently appeared to drive and protect the refugees in Virgil's Aeneid -- and who might be expected to bring in the new age. The second night was devoted to the Eilithyia, the Greek child-birth deity. The third addressed the Mother of the earth.

\footnotetext{
${ }^{7}$ Virgil, Eclogues IV, of course, as well as V, $78 \mathrm{f}$. and IX, 47-48. And again Horace, Epodes, xvi, which admits both optimistic and pessimistic readings. Ovid, Fasti III, 159 f. Manilius, Astronomica V, 734-739.

${ }^{8}$ This bit of Varro's de gente Populi Romani has been preserved in Augustine, de Civ. Dei XXII, xxviii.

${ }^{9}$ Zosimus, Historia Nova II, 5.

${ }^{10}$ Zosimus II, 1-4. The Sybilline oracle is recorded in cap. 6.
} 
All this evening business had a strong Greek flavor to it, redolent (so far as we know about it) of the Greek underworld cults, of initiations and death to an old, guilt-stained life after the fashion of the ancient Eleusinian mysteries. ${ }^{11}$ (Dodds 1972, Fowler 1911) Augustus finished with a sort of pastoral prayer for the health of the state, and of his house and "familia", in which were grouped in mystic fashion all the citizens present. ${ }^{12}$ (Fowler 1911)

The actual heralding and founding of the newly regenerated era were carried on in broad daylight. On 1st and 2nd June Augustus and Agrippa sacrificed to the gods of the Capitol in grand convocation after the ancient manner. One hundred and ten select matrons carried out the particulars of the services beginning on the 2nd foreshadowing, hopefully, the fertility and propriety of the coming age for at least the 110 years Atreius Capito had reckoned it to last. ${ }^{13}$

On the final day, however, the scene opened not on the Capitol but on the Palatine, in front of the great temple to Apollo which Augustus had built adjoining his house, and of which he sounds so proud in the Res Gestae. ${ }^{14}$ This was the 3rd of June. Before the assembled crowd in the court a chorus of 54 boys and girls sang a hymn summing up the purifications and rebirth, and dedicating the people to a new age of Romanitas -- of piety, humility, morality and religious scruple.

This was Horace's Carmen Saeculare as experienced in its living context, not tossed as it often is into a collection of the poet's detached and ironic pieces. Sung in this setting it seems genuinely to have moved its crowd and many hearts thereafter, and may have had the sort of curiously strong impact we sometimes feel from Byzantine or Victorian public devotional lyrics -- so packed with deities and prospective virtuous states of mind that it must have strained even Horace's skill at finely-inlaid poetic miniature-work to fit it all in.

"... If Rome is your workmanship,

And bands from Ilium reached the Tuscan shore,

a number bidden to change, by a prosperous voyage,

Their household gods and city;

For whom unharmed through burning Troy, holy Aeneas,

Outliving his country, opened a free path

He, destined to give them more than they had left;

--Ye gods, grant fair morals to a trainable youth;

${ }^{11}$ It bears useful comparison with the Homeric Hymn to Demeter $480 \mathrm{ff}$. Cf. Dodds, Greeks and the Irrational (Berkeley, 1981), pp. 137, 172 n. 102, 258 n. 29; Ancient Concept of Progress, p. $145,148 \mathrm{f}$. Also Fowler, op cit.

${ }^{12}$ After the manner of the landowner in Cato's Res Rustica (e.g. the formulae in CXXXII and CXXXIV), including all the folk in his agricultural community within his spiritual familia. Cf. Fowler, Rel. Exp., p. 449 n. 42.

${ }^{13}$ On the Augustan particulars in the rituals, C.I.L. VI, xxxii, 323; Ephemeris Epigraphica, viii, $255 \mathrm{ff}$.

${ }^{14}$ Res Gestae 21 . 
Ye gods to quiet old age grant repose ..."15

The effect when read out of context may indeed be very, very flat, and the suggestion that Augustus himself may have drawn up the prosaic matter of the piece rather thoroughly ${ }^{16}$ (Fowler 1911: 145, Ogilvie 1969: 116) still seems to me likely whenever I read it. What startles or disturbs many modern critics is the emotional force it seems to have carried in (and for years afterward, from) its setting and its connection to the heart of its audience. Peter Levi, who is obviously himself uncomfortable with its religious tone and the success of its appeal, recently called it "perhaps the most successful publicly commissioned poem in the history of poetry." (Levi 1998: 207.)

It must have carried a different and far more powerful effect when delivered in its original setting. Across the Forum the temples of the Capitol would be the primary objects in view. A little to their left, further off, lay the site of the evening sacrifices -- many of those whose eyes trailed from the new religious heart of the city to the spread of the river and the Campus Martius would have followed the processions that way on the previous nights. Behind the chorus, on the fastigium of the new temple, rose a sculptured relief of Apollo in his four-horsed chariot driving away the Gauls (symbols of chaos in the propaganda of Augustus and they had been in Caesar's, and in that of Pergamum before them) by means of thunderbolts. ${ }^{17}$ As the chorus sang various parts of the hymn, and moved to indicate with rhythmic gestures the seats of the various deities invoked, it brought back to those attending each rite of the week with some recollection of its meaning, or at least of its flavor and emotion.

"Phoebus [Apollo] and Diana of the forest

Bright glory of the heaven sublime,

Worshipped and to be worshipped, grant our request

In a holy time,

When warned by the verses of the Sybils

These pure boys and these chosen girls who belong

To the gods who have loved the seven hills

Repeat this song.

Kindly sun in your chariot gleaming,

Bringer and taker of day, for ever reborn

Fresh and the same, may you never see anything

Greater than Rome. ...

...May the prophet glorious with his gleaming bow

\footnotetext{
${ }^{15}$ Horace, Carmen Saeculare, 11. 37-46.

${ }^{16}$ See Fowler's article and R.M. Ogilvie. The idea was never one to please classicists, and needs more argument.

${ }^{17}$ Propertius, ii, 31-40.
} 
Phoebus to whom nine Muses sing their hymns

Who with his saving art rescues from sorrow

Our weary limbs,

If he looks kindly on his Palatine

Altars continue happy Latium

And Roman wealth, and better things combine

In the age to come."18

This focus of the heart on things greater than itself, connecting them to moral renewal, the hymn was at least meant to do, and I think we fall far short of understanding the occasion unless we realize that if only one Roman was moved deeply, that one was Augustus. This was most particularly true where the hymn and the ritual touched on the temple and work of Apollo. It is to Apollo we must now turn.

The most important deities of the revolutionary and Augustan ages were not those of archaic times -- those that tended the soil or those that could as E.R. Dodds once said "keep an enemy spear from your vitals". One apparent exception to this -- Mars Ultor -- I must postpone a little. Neither were they those particularly good for business like Hermes, or Castor and Pollux. They were rather the deities that could defend man against chaos threatening to engulf him from without, and from guilt or impurity or jaded impiety (all a result of a world that felt itself somehow dislocated in its relation to heaven) destroying man from within. The three great helpers in this regard were:

- Dionysus, who could remove the guilt or anxiety, and presumably the jadedness, by simply throwing away one's inhibitions temporarily and allowing a rush of catharsis. By a manic plunge back into the divine mind one could get a great many interior things back into harmony again.

- Hercules, who was powerful enough to stand off the forces of chaos, but was especially valuable to that age because he had once been human. ${ }^{19}$ (Johnson et al 1961, Price 1984) "He was touched by "the feeling of our infirmities," to borrow a phrase from the later Christians. Hercules was always presumed to have time for the humble and down-trodden.

- Apollo, who had always been the one source of clarity, light and communication whenever the rest of the Greek (and now the Roman) cosmos grew dark, uncertain, hostile. He could "tell you what to do when you felt anxious or frightened; he knew the rules of the complicated game

\footnotetext{
${ }^{18}$ Horace, Carmen Saeculare, 11. 1-20, 60-72, again in Peter Levi's version, Horace, pp. 207-209.

${ }^{19}$ Price is better with the details than with the feeling of the evidence he handles in my view, but has some enlightening points to make about the role of Roman provincial magistrates in personalizing and even Romanizing the Hellenic view of Augustus.
} 
that the gods play with humanity; he was the supreme alexikakoz, 'Averter of Evil'." 20

And any one of these, oddly enough, could be made to have something to do with human arts in general, and government in particular. Dionysus was the patron or theatre in the sense of being Master of Illusion. He was naturalized by the Hellenistic monarchs, especially in Egypt, who drew a great deal of temporal and emotional power from pageantry and display of wealth. Hercules had an old connection with the Muses, though it might seem surprising. He could understand and sympathize with human acts or struggles, and at the same time hopefully keep them from losing their proper proportion, from provoking the jealousy of the gods. A laborer in a moment of great effort was much safer saying "Hercule!" than " $O$ Dionysus!" or (much worse) "'O Zeus!"

This last attitude seems to have been the one taken by the new emperor's father, Philippus; it implied the humility he seems always to have tried to impress upon Octavian, but Octavian on the way to becoming Augustus chose Apollo as his defining principle instead. There was more to this than the happy accident of an Apolline temple overlooking the bay at Actium. ${ }^{21}$

Apollo had been evoked into and naturalized as a part of Rome in response to natural disaster in the year 431 of the old era. ${ }^{22}$ He had been the protecting god of Troy, and Virgil in due course had his Aeneas land at the same holy site Octavian would one day camp beneath. In fact, Apollo carried enough religious weight with the young Octavian that Virgil could begin his fourth eclogue (which had been written by 40) with the words "Your Apollo now reigns". Octavian may have made a small dedication to Apollo on the Palatine as early as $36 .^{23}$ A thunderbolt hit the hill in 28 , making the place unchancy even to a skeptical mind of those times. $^{24}$

Augustus saw no ambiguity in the message and set about temple-building quickly, later adding an impressively endowed library to its precincts. ${ }^{25}$ Apollo had I think been a useful guardian and identification at first simply because of the contrast with Antony, who had taken to Dionysus (and Egypt, and a queen who was heir in spirit to the old ecumenical culture-leveler Alexander). But the more he saw the forces of chaos, the less did Octavian wish to defeat them by becoming one of them. Apollo offered access, by contrast, to clarity, rightness, the sense of

\footnotetext{
${ }^{20}$ Dodds, Greeks and the Irrational, p. 75. Cf. Aeschylus, Eumenides, $616 \mathrm{ff}$.

${ }^{21}$ Propertius IV, vi, 29 ff. Cf. J. Gagé, Apollon Romain (Paris, 1955), pp. 229, 515. Compare Syme, The Roman Revolution (Oxford, 1939), p. 448, where a "happy" accident is almost all it is.

${ }^{22}$ Gagé, op cit.

${ }^{23}$ Ogilvie, Romans and their Gods, p. 114.

${ }^{24}$ Propertius, ii, 31. Suetonius, Augustus, 29. On Augustus, cf. Fowler, Rel. Exp., p. 305.

${ }^{25}$ Suetonius, Augustus XXIX, 3.
} 
things, inspiration to decisions that could harmonize with heaven. ${ }^{26}$ To a Roman enmeshed in the business of becoming Augustus, full of private weaknesses, ironies and misgivings, Apollo seemed though Greek to offer the best chance at a return to intelligent, fertile Romanitas.

So the Saeculares ended under the porch and chariot of Apollo. Augustus made, or hoped he had made, a choice for his extended familia and subjects - a choice against the whole previous century of their heritage. He chose for them instead an image of the best things his optimistic and world-weary scholars could discover in the centuries before.

\section{A Note on the Final Part of this Study}

My goal here was, within compact limits, to re-create some of the flavor and focus of the Ludi Saeculares while expelling the 'red herring' sense of games or celebration we dismiss them with. This was serious business to Augustus, but of course while he could engineer effort and pageantry (and even to some degree the acts of belief), he could not engineer results in human nature. Some of the outcomes and legacy of the year 17 I explore in the final part, which can be found in Wick (2019b).

\section{Acknowledgements}

This material written for presentation at the ATINER $14^{\text {th }}$ Annual International Conference on History \& Archaeology: From Ancient to Modern, Athens, Greece, 2016, and revised with feedback from that presentation. My thanks to all who contributed, however informally.

\section{References}

\section{Modern References}

Dittenberger W (1905) Orientis Graeci Inscriptiones Selectae [Corpus posts Selections]. Leipzig: Hirzel.

Dodds ER (1972) The Ancient Concept of Progress. Oxford: Clarendon Press.

Ehrenberg V, Jones AHM (1949) Documents Illustrating the Reigns of Augustus and Tiberius. UK: Oxford UP.

Fowler WW (1911) Religious Experience of the Roman People. Fili-Quarian Classics. Gagé J (1955) Apollon Romain. Paris.

${ }^{26} \mathrm{Cf}$. Horace, Odes I, xxxi, which redefines Apollo's sphere of blessing toward a very modest harmony of life. 
Gruen E (1974) The Last Generation of the Roman Republic. Berkeley: University of California Press.

Jeanmaire H (1924) La Politique Religieuse d'Antoine et Cléopatre [The religious policy of Antoine and Cleopatra]. Revue Archéologique 19: 241-261.

Johnson AC, Coleman-Norton P, Bourne F (eds) (1961) Ancient Roman Statutes. Austin: University of Texas Press.

Jones AHM (1970) Augustus. New York: W.W. Norton \& Company.

Levi P (1998) Horace: a Life. New York: Tauris Parke Paperbacks.

Lewis N, Reinhold M (eds) (1966) Roman Civilization. New York: Columbia University Press.

Mazzolani LS (1970) The Idea of the City in Roman Thought. Indiana: Indiana University Press.

R.M. Ogilvie (1969) The Romans and their Gods in the Age of Augustus. New York: W. W. Norton \& Compan.

Pasquali G (1931) Cesare, Posidonio e Platone, pp. 297 ff., in Studi Italiani in Filologia Classica.

Price SRF (1984) Rituals and Power: the Roman Imperial Cult in Asia Minor. Cambridge: Cambridge University Press.

Scott K (1933) The Political Propaganda of 44 - 30 B.C. Bergamo: American Academy in Rome.

Syme R (1939) The Roman Revolution. Oxford: Oxford University Press (the starting-point for readers to get a contrasting view of these concerns and efforts as pure politics and social engineering).

Taylor LR (1931) Divinity of the Roman Emperor. Ayer Co Pub. (See first part of this study, or consult for the mid-twentieth century 'take' - again as social engineering).

Wick D (2019a) Augustus and the problem of the Pax Deorum - A Case Study in social \& religious motives at the birth of the Roman Empire. Athens Journal of Mediterranean Studies 5(1): 1-10.

Wick D (2019b) Augustus - making a legacy of the Pax Deorum Aspects of a Pagan attempt at religious revival shortly before the birth of Christ. Athens Journal of History (forthcoming).

Ancient References (each locus in notes as appropriate)

Appian, Civil Wars

Augustus, Res Gestae

Cicero, Ad Atticus, Ad Quintus, De Officiis,

Dio Cassius, Histories,

Horace, Odesm Carmen Saeculare

Livy, Histories (esp bk. III)

Nepos, Lives (esp. Atticus)

Plutarch, Antony, Pompey, Crassus, Caesar, Cato

Pompeius Trogus, $\underline{\text { History of Rome }}$

Seneca, de Beneficiis, De Brev. Vitae

Suetonius, Augustus, Julius Caesar

Velleius Paterculus, $\underline{\text { History of Rome }}$

Zosumus, Historia Nova 